\title{
New Jersey outlaws genetic discrimination
}

Washington. The New Jersey state legislature last week gave near-unanimous approval to the most sweeping bill outlawing genetic discrimination yet passed in any of the 50 states.

But a controversial clause giving an individual property rights to genetic information was dropped after pressure from the biotechnology and pharmaceutical industries that are well represented in the state.

The bill is expected to be signed into law by New Jersey Governor Christine Todd Whitman (Republican) this week. It not only outlaws the use of genetic information to deny individuals jobs or health insurance, but also restricts how life and disability insurers may use such information.

In its revised form, the bill has received the backing of a wide range of interest groups, including the two industries involved, labour unions and the Roman Catholic church. The only obvious dissent has come from insurance groups, which testified against the bill last spring. They argue that insurers need all the information possible about applicants to accurately assess risk and avoid driving up rates on individual policies. They are said to have been "reluctantly coerced" into supporting the legislation.
Whitman had vetoed the bill in September, after both houses of the legislature had passed it unanimously (see Nature $\mathbf{3 8 3}, 367$; 1996). Her position reflected the concerns of the biotechnology and pharmaceutical industries, which had objected to a statement in the bill declaring genetic information to be an individual's private property.

The governor and the industries argued that this could have a 'chilling' effect on research, by exposing companies to law-suits for royalties by those whose DNA had been used to develop new products.

The property right declaration was subsequently removed from the bill. Supporters of the clause say that the political power of the pharmaceutical and biotechnology industries left them with little choice - but that the issue was a relatively minor concern when compared with the bill's broad antidiscrimination provisions.

Even in its modified form, the bill is "absolutely more far-reaching than any other", says Generosa Grana, a breast cancer specialist at Cooper Hospital in Camden, New Jersey, and an adviser to the New Jersey Cancer Commission, who helped draft the bill.

None of the advocacy groups fought

\section{Gene tests 'need research protocols'}

Washington. An advisory committee to the National Institutes of Health (NIH) has recommended that genetic testing for breast and ovarian cancer be conducted only within strictly defined research protocols. This reverses an earlier position encouraging wider use of testing (see Nature, $\mathbf{3 8 0}, \mathbf{5 7 3} ; \mathbf{1 9 9 6}$ ).

Last week, the Advisory Committee on Research on Women's Health unanimously passed a resolution urging that genetic tests for breast and ovarian cancer be conducted only within "hypothesis-driven protocol studies" endorsed by $\mathrm{NIH}$-approved institutional review bodies.

Typical studies, says the resolution, might address questions such as the positive predictive value of tests, and the appropriate medical management of those carrying mutations. The advice represents a refusal to endorse commercial genetic testing that does not incorporate hypothesis-driven research.

Last April the committee refrained from calling for testing to be confined to research protocols. One dissenter at the time was Linda Burhansstipanov, director of the Native American Cancer Research Program at the AMC Cancer Research Center in Denver, Colorado, who called the resolution "paternalistic". But last week she supported the revised resolution, after the committee added a new, lengthy preamble. It includes a call for research on how poor, non-white and rural women can be guaranteed access to testing under research protocols.

Vivian W. Pinn, director of the NIH's Office of Research in Women's Health, says she agrees with the advisory committe. Access to genetics testing is important, but women "should know what it means", and such information is more likely to be both gathered and imparted in the research setting.

In adopting its position, the advisory committee joins the American Society of Human Genetics, the Advisory Council of the National Center for Human Genome Research, and the National Breast Cancer Coalition. In contrast, the American Society of Clinical Oncology has called for genetic testing to be made available outside research settings "as part of the preventive oncologic care of families".

The new recommendation comes two weeks after Myriad Genetics of Salt Lake City introduced commercial fullsequence testing of BRCA1 and BRCA2 genes, mutations which can confer a predisposition to breast and ovarian cancers. The company is charging $\$ 2,400$ for initial testing, and $\$ 395$ for tests of additional family members.

M.W.
Whitman's demanded change "because there was so much [else] to lose", adds Karen Rothenberg, director of the Law and Health Care Program at the University of Maryland School of Law, and an expert on state genetic discrimination laws.

Not everyone agrees. George Annas, a lawyer and professor of public health at Boston University School of Public Health, says that "gutting" the property right clause has turned the bill into "an anti-genetic privacy act". He called it "bizarre" that "other people can own your genetic information, but you can't". And State senator Robert Martin (Republican), a law professor who was the lone Senate opponent of the revised bill, argues that Whitman's concern to protect industry may not have given enough protection to ordinary citizens.

The strength of the bill lies in its prohibition of discrimination not only on the basis of genetic tests, but of genetic information - a far broader term which includes family history, and can include individual history, physical examination and the results of other tests.

The bill is also broad in scope. It imposes restraints on life and disability insurers, in addition to employers and health insurers. Laws in other states have been narrower.

Under the bill, neither genetic information, nor an individual's refusal to submit to a genetic test or provide test results, can be used in decisions on hiring, firing and health insurance. Life and disability insurers may demand and use genetic information in underwriting, but must not use it 'unfairly'.

A life insurer, for example, could not use the fact that a woman is carrying a BRCAI mutation to decide whether to issue a policy, or what rate to charge, because this fact is no guarantee that she will develop cancer.

But the same insurer could legally refuse cover or charge higher premiums to somebody who carries the gene for Huntington's disease, as that person has a 100 per cent chance of developing the disease. In such a case, the insurer would have to base rates on actuarial data for Huntington's patients.

Only one state - Oregon - of the 12 others that have passed laws dealing with genetic discrimination includes a property right. An official now implementing the Oregon law says that the property right does not seem to have had any immediate impact. Michael Skeels, director of the state's Public Health Laboratory, adds that its implications for research will "take years" to become clear.

Earlier this year, the US Congress passed a law merely forbidding health insurers from using genetic information to discriminate against people who change or lose jobs. Pressure is growing for a broader federal law, and the issue may be addressed in the next legislative session. Meredith Wadman 